\title{
Perancangan Unit Mesin Pendingin (Cold Storage) untuk Produk Karkas Sapi Kapasitas 25 Ton dengan Kombinasi Refrigerasi Kompresi Uap, Refrigerasi Absorpsi, dan Flat Plate Solar Collector di Kabupaten Pamekasan-Madura
}

\author{
Canny Cado Dwi Putri Ayu, Budi Utomo Kukuh Widodo, dan Prabowo \\ Departemen Teknik Mesin, Fakultas Teknologi Industri, Institut Teknologi Sepuluh Nopember (ITS) \\ e-mail:budiitem@me.its.ac.id
}

\begin{abstract}
Abstrak-Pamekasan merupakan kota dengan potensi yang besar dalam bidang peternakan, yaitu produksi karkas sapi. Bahkan, proses ekspor sering dilakukan oleh masyarakat lokal ke berbagai daerah di luar Madura. Namun, mereka memilih cara yang salah dalam proses distribusi karkas. Mereka mengirim sapi dalam keadaan hidup dan melakukan proses penyembelihan di tempat tujuan. Proses ini akan lebih baik jika karkas terlebih dahulu dibekukan. Oleh karena itu, dibutuhkan desain cold storage. Pamekasan juga memiliki potensi iradiasi yang cukup, sehingga desain menggunakan solar collector jenis datar. Perancangan meliputi konstruksi dan sistem pendinginan, yaitu kombinasi refrigerasi kompresi uap dan absorpsi. Ammonia (R717) sebagai refrigeran dan Aquos-ammonia sebagai absorben-refrigeran pada absorpsi. Hal ini bertujuan agar karkas kapasitas 25 ton dapat didinginkan hingga temperatur $-\mathbf{2 0}^{\circ} \mathrm{C}$. Variasi yang digunakan dalam proses perancangan yaitu persentase ammonia larutan lemah $10 \%, 20 \%, 30 \%$, dan $40 \%$ untuk menentukan COP dan luas solar collector teroptimal. Hasil yang diperoleh yaitu beban maksimal 251,922 KW pada 15 jam pendinginan bulan Januari; nilai COP kompresi uap 3,375; COP optimal untuk refrigerasi absorpsi 0,794; luas solar collector $300,702 \mathrm{~m}^{2}$; dan pemilihan komponen sistem berdasar katalog.
\end{abstract}

Kata Kunci-Absorpsi, Cold Storage, Solar Collector.

\section{PENDAHULUAN}

$\mathrm{P}$ ROYEKSI konsumsi daging sapi nasional tahun 2016 mencapai 738.025 ton. Bahkan, pemerintah mendatangkan daging sapi impor untuk memenuhi kebutuhan pangan masyarakat sebanyak 268.790 ton karena produksi lokal hanya berkisar 469.235 ton. Kabupaten Pamekasan merupakan salah satu daerah dengan produksi daging sapi tertinggi di Pulau Madura. Produksi daging sapi di Kabupaten Pamekasan mencapai rata-rata 2.656 ton setiap bulan menurut Dinas Peternakan Pamekasan, sehingga tidak membutuhkan daging impor dan sudah cukup memenuhi kebutuhan daging warga Pamekasan. Bahkan tidak sedikit yang disuplai ke luar daerah, seperti daerah Situbodo dan Bondowoso melalui jalur laut. Namun, distribusi daging dilakukan dengan cara yang tidak efektif, yaitu dengan cara mengangkut sapi dalam keadaan hidup agar proses penyembelihan dapat dilakukan di tempat tujuan untuk mempertahankan kualitas daging. Proses distribusi akan jauh lebih efektif jika karkas dibekukan terlebih dahulu.

Pemanfaatan energi matahari sesuai dengan potensi wilayah Pamekasan yang memiliki intensitas radiasi matahari cukup besar, menurut GeoModel Solar; dengan kisaran 1900 hingga $2100 \mathrm{kWh} / \mathrm{m}^{2}$ dan beriklim tropis dengan temperatur rata-rata tahunan berkisar antara $26-28^{\circ} \mathrm{C}$ dan beriklim Aw menurut klasifikasi Köppen-Geiger dengan curah hujan lebih rendah daripada tropis. Oleh karena itu, Optimalisasi potensi daerah Pamekasan dengan melakukan perancangan unit cold storage dengan kapasitas 25 ton karkas memanfaatkan energi matahari menggunakan flat plate solar collector dengan siklus kombinasi absorpsi dan kompresi uap untuk proses pembekuan daging sapi hingga temperatur $-20^{\circ} \mathrm{C}$ bagi wilayah produsen daging di Pamekasan.

\section{METODOLOGI PERANCANGAN}

\section{A. Tahap Permodelan Sistem Pendingin}

Sistem refrigerasi yang akan digunakan yaitu kombinasi refrigerasi kompresi uap, absorpsi, dan sistem pengumpul energi matahari jenis plat datar. Energi matahari akan dikumpulkan dan digunakan untuk memanaskan generator pada sistem absorpsi, sehingga uap refrigeran murni dialirkan menuju kondensor, katup ekspansi, dan evaporator. Uap yang keluar dari evaporator menuju mixing chamber (absorber) dan dialirkan menuju generator dengan pompa dalam bentuk ammonia larutan kuat (strong solution), sedangkan pada generator sebagian larutan aquos-ammonia dialirkan kembali menuju absorber melalui katup ekspansi dengan kondisi larutan ammonia lemah (weak solution).

Evaporator pada refrigerasi absorpsi akan menjadi kondensor pada refrigerasi kompresi uap. Refrigerasi ini menggunakan 4 komponen utama, yaitu; kondensor, katup ekspansi, evaporator, dan kompresor. Refrigeran yang mengalir dalam sistem kompresi uap adalah ammonia murni. Refrigeran yang keluar dari kondensor berupa cair jenuh mengalir menuju evaporator melalui katup ekspansi. Refrigeran yang keluar melalui evaporator berupa uap ammonia menuju kompresor dengan menaikkan tekanan hingga sama dengan tekanan kondensor. Skema perancangan sistem pendingin seperti pada gambar 1. 


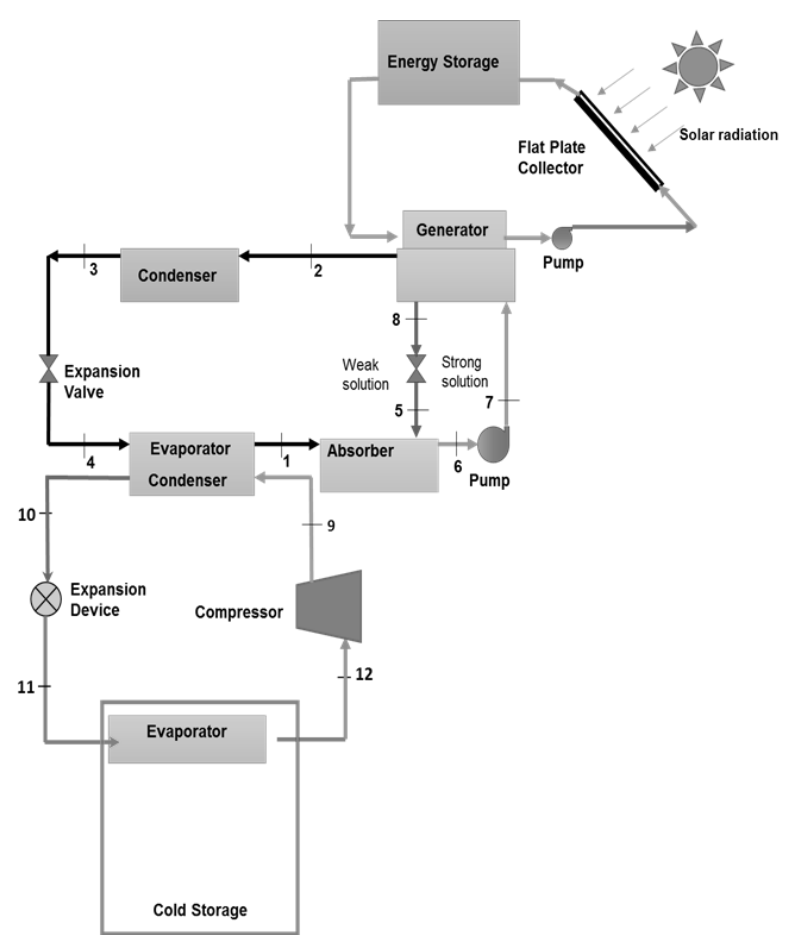

Gambar 1. Permodelan Sistem Pendingin pada Cold Storage

\section{B. Tahap Permodelan Konstruksi Cold Storage}

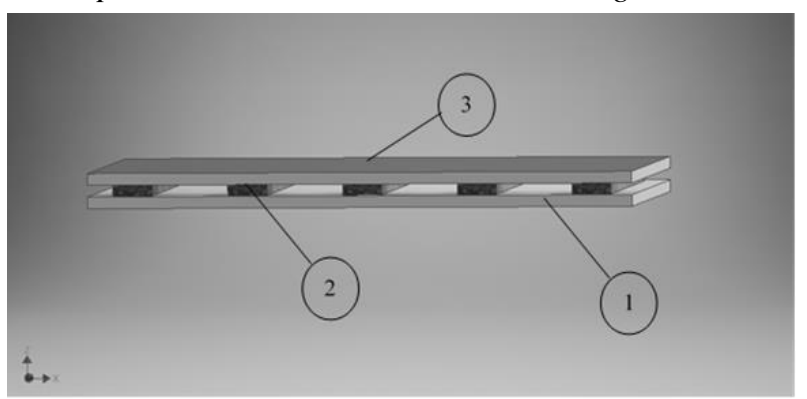

Gambar 2. Permodelan Atap (Ceiling); (1)Pondasi Bagian Atas Atap, (2)Penyangga Atap (Joist), dan (3)Atap Bagian Atas Cold Storage

Material yang digunakan untuk ceiling yaitu; 6 in h.w concrete dengan insulasi 2 in. Atap yang didesain adalah jenis Flat Roof dengan Suspeded Ceiling. Lantai yang didesain menggunakan material Metal lath dan lightweight aggregate 0,75 in, joist, wood subfloor 0,75 in, plywood 0,625 in, felt building membrane, dan resilient tile.

Penampang dinding cold storage pada gambar 3b) menggunakan material insulasi yang sangat baik, yaitu; polyurethane dan gipsboard. Rancangan pintu yang digunakan yaitu jenis swing door dengan diletakkan sebuah jendela kaca $0,08 \mathrm{~m}^{2}$. Pintu menggunakan material solid urethane foam core, sedangkan jendela kaca menggunakan flat glass dan lapisan tunggal (single glass) seperti gambar 3a). Dimensi Cold Storage yaitu panjang $5 \mathrm{~m}$, lebar $4 \mathrm{~m}$, dan tinggi $2 \mathrm{~m}$. Daya tampung maksimal cold storage yaitu 25 ton.

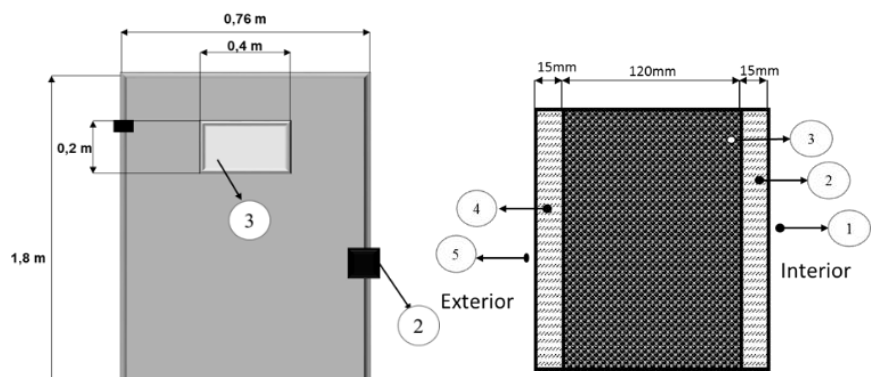

b)

Gambar 3. a)Permodelan Pintu Cold Storage; (1)pintu, (2)gagang pintu, (3)jendela kaca, (4)engsel pintu; b)Penampang Dinding Cold Storage; (1)interior, (2)dan(4) gipsboard, (3)polyurethane, (5)eksterior.

\section{HASIL DAN PEMBAHASAN}

\section{A. Beban Pendinginan}

\section{1) Beban Eksternal}

Beban eksternal terdiri dari beban dinding.jendela kaca, pintu, lantai, dan atap. Perhitungan dilakukan sesuai dengan standar ASHRAE. Berikut ini hasil dari perhitungan beban pendinginan.

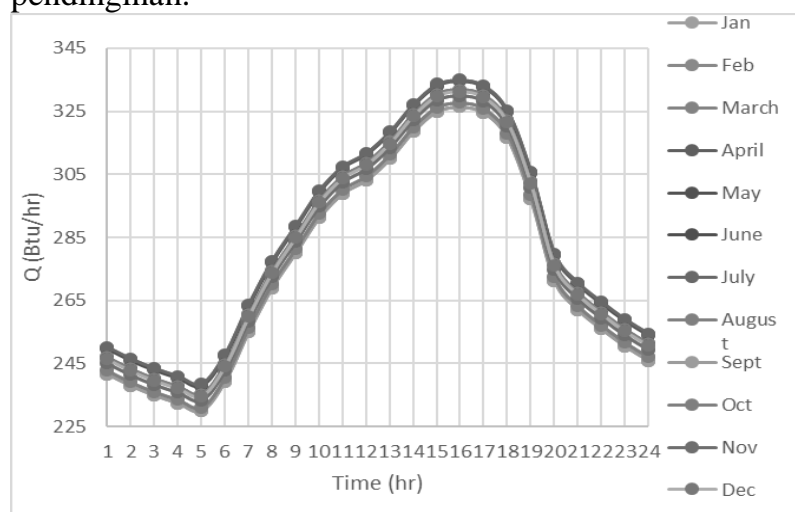

Gambar 4. Grafik Beban Pendinginan oleh Dinding Cold Storage Fungsi Waktu Pendinginan (dalam 1 tahun)

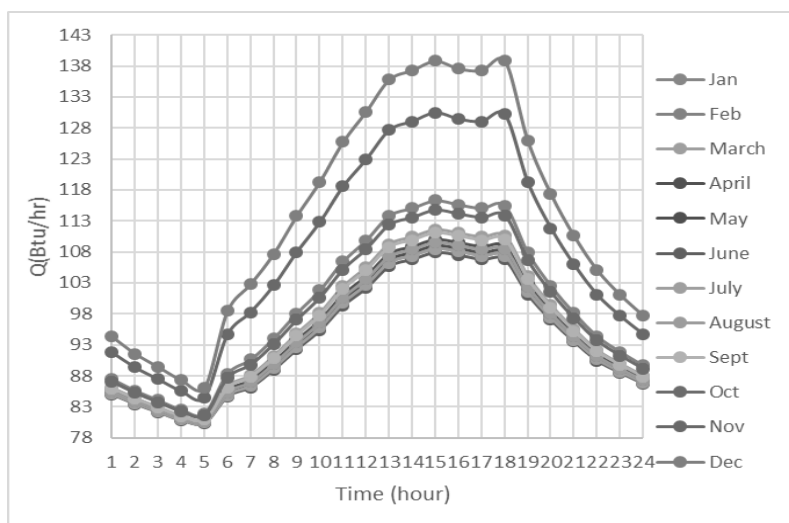

Gambar 5. Grafik Beban Pendinginan oleh Jendela Kaca Cold Storage Fungsi Waktu Pendinginan (dalam 1 tahun)

Gambar 4 menjelaskan bahwa nilai beban dinding tertinggi terjadi pada bulan Juli. Peningkatan beban terjadi setelah 5 jam pendinginan hingga mencapai beban maksimal pada 16 jam pendinginan dan kembali mengalami penurunan. Gambar 5 menjelaskan bahwa nilai pembebanan oleh kaca tertinggi yaitu 
pada bulan Desember. Hal ini sesuai dengan teori, karena pada bulan Desember, letak matahari rendah di sisi sebelah selatan. Oleh karena itu, sudut inklinasi matahari terhadap dinding menimbulkan pembebanan yang paling besar untuk bulan Desember. Kenaikan beban pendinginan dimulai saat 5 jam waktu pendinginan hingga mencapai nilai maksimal pada 15 jam pendinginan, kemudian menurun hingga 24 jam pendinginan. Begitu pula seterusnya.

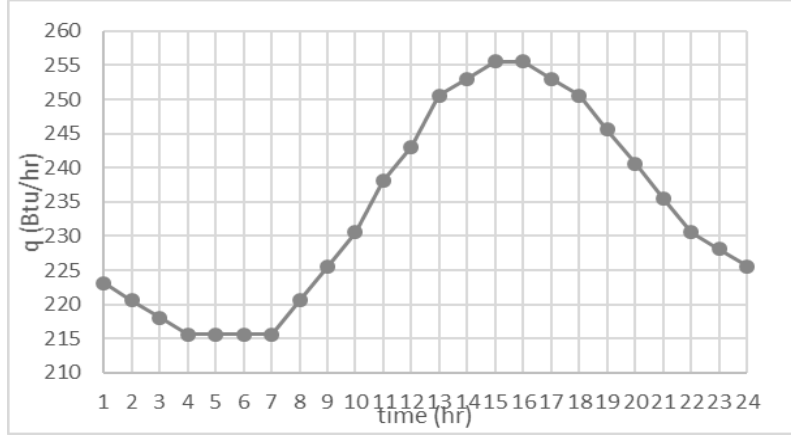

Gambar 6. Grafik Fungsi Beban Pendinginan Pintu terhadap waktu

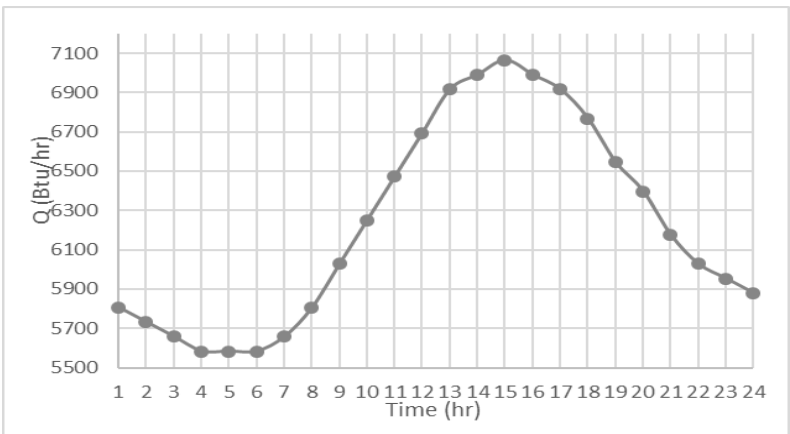

Gambar 7. Grafik Fungsi Beban Lantai terhadap waktu

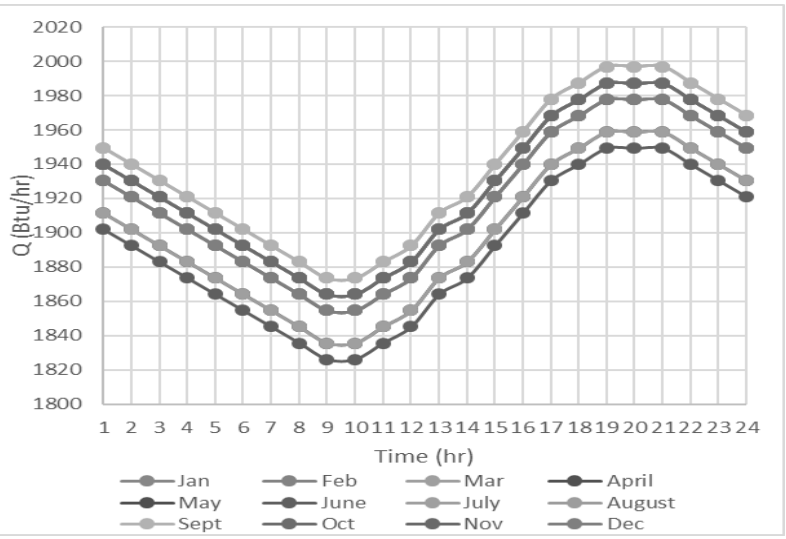

Gambar 8. Grafik Beban Atap Fungsi Waktu (dalam 1 tahun)

Gambar 6 menunjukkan bahwa beban pintu menurun hingga 4 jam pendinginan dan kembali meningkat pada 7 jam pendinginan hingga mencapai kondisi maksimal pada 16 jam pendinginan hingga akhirnya kembali menurun hingga 24 jam pendinginan. Gambar 7 menunjukkan bahwa terjadi penuruna beban lantai hingga 4 jam waktu pendinginan yang kemudian meningkat pada 7 jam hingga mencapai nilai maksimal pada 15 jam pendinginan. Kemudian, grafik kembali mengalami penurunan beban hingga 24 jam waktu pendinginan. Beban pintu dan lantai setiap bulan besarnya sama karena tidak dipengaruhi oleh lattitude month dan arah sinar matahari.
Gambar 8 menunjukkan bahwa terjadi penurunan beban atap dari awal pendinginan hingga 9 jam, kemudian meningkat hingga mencapai nilai maksimal pada waktu 21 jam, kemudian kembali menurun hingga 24 jam. Hal ini dipengaruhi oleh waktu penyinaran matahari. Nilai beban atap paling tinggi untuk Lattitude Month (LM) pada 8 LS yaittu pada bulan September.

2) Beban Internal

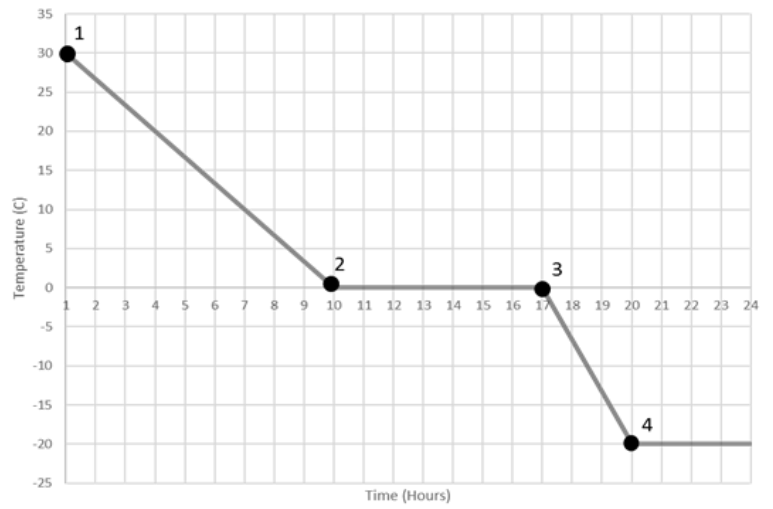

Gambar 9. Distribusi Temperatur Karkas terhadap Waktu Pendinginan

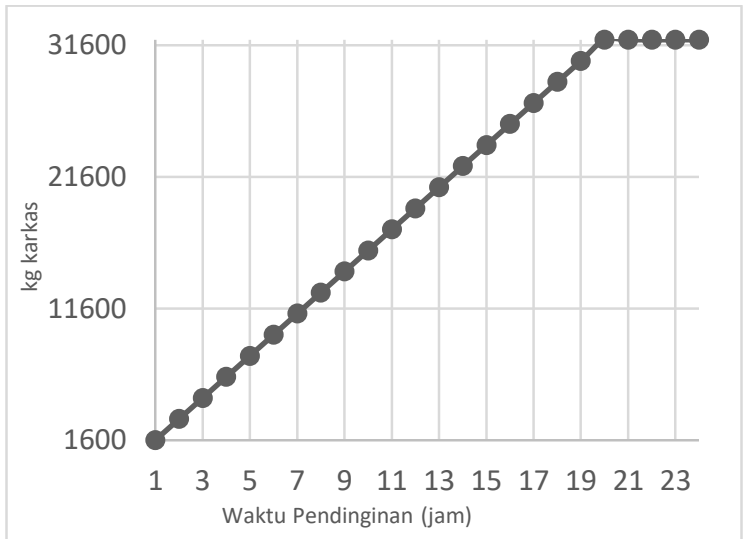

Gambar 10. Penambahan Karkas Sapi dalam Cold Storage

Karkas didinginkan mulai temperatur inisial 30 hingga -20 . Sensible heat terjadi pada proses 1-2; yaitu penurunan temperatur dari $30^{\circ} \mathrm{C}-0^{\circ} \mathrm{C}$ dengan kalor sensibel rata-rata sebesar 116937,808 Btu/hr dan proses 3-4 yaitu penurunan temperatur dari $0^{\circ} \mathrm{C}-(-20)^{\circ} \mathrm{C}$ dengan kalor sensibel sebesar $300819,331 \mathrm{Btu} / \mathrm{hr}$. Latent heat terjadi pada proses 2-3 yaitu perubahan fasa karkas menjadi es dengan rata-rata kalor $767880 \mathrm{Btu} / \mathrm{hr}$. Waktu pendinginan diperoleh dari hasil perhitungan konduksi transien. Proses 1-2 terjadi selama 10jam, proses 2-3 terjadi selama 7 jam, dan proses 3-4 selama 3 jam. Total jam pendinginan yaitu 20 jam.

Massa karkas yang digunakan pada proses perhitungan yaitu $60 \%$ dari massa total karena kandungan air dalam karkas sebesar $60 \%$, 22\% lemak, dan lainnya merupakan tulang. Kapasitas Maksimal pendinginan karkas yaitu 767880 $\mathrm{Btu} / \mathrm{hr}=225043,413 \mathrm{~W}$. Energi yang dibutuhkan pendingin yaitu 5401041,918 Wh/hari. Gambar 10 menjelaskan tentang perbandingan beban internal dan eksternal cold storage. Beban diperhitungkan berdasarkan jam matahari. Beban internal 
konstan sesuai dengan kapasitas pendinginan maksimal produk, yaitu $767880 \mathrm{Btu} / \mathrm{hr}$.

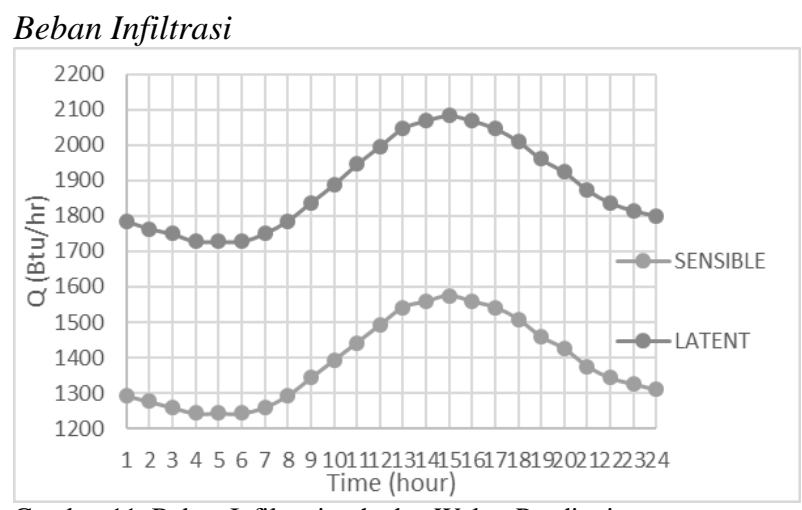

Gambar 11. Beban Infiltrasi terhadap Waktu Pendinginan

Gambar 11 menunjukkan beban laten dan sensibel oleh infiltrasi terhadap waktu pendinginan. Beban laten memiliki nilai yang jauh lebih besar daripada beban sensibel. Kedua beban ini mengalami penurunan hingga 5 jam pendinginan dan meningkat hingga mencapai nilai maksimal pada 15 jam pendinginan. Setelah itu, beban kembali menurun hingga 24 jam pendinginan.

\section{Total Beban Pendinginan}

Beban pendinginan total diperhitungkan hingga 24 jam pendinginan setiap bulan dalam setahun. Sehingga, diperoleh beban tertinggi yaitu pada bulan Januari pada 15 jam pendinginan sebesar 859595,541 Btu/hr atau 251922,585 Watt, setara dengan 0,251 MW

\section{B. Sistem Kompresi Uap}

Tabel 1.

Data Tiap Keadaan untuk Sistem Kompresi Uap

\begin{tabular}{cccc}
\hline \hline $\begin{array}{c}\text { State } \\
\text { points } *\end{array}$ & $\begin{array}{c}\text { Tekanan } \\
(\mathrm{bar})\end{array}$ & $\begin{array}{c}\text { Temperatur } \\
\left({ }^{\circ} \mathrm{C}\right)\end{array}$ & Kondisi \\
\hline 9 & 14 & 130 & $\begin{array}{c}\text { Superheated vapour } \\
\text { Saturated liquid }\end{array}$ \\
10 & 14 & 36,26 & $\begin{array}{c}\text { Throttling; isoenthalpy; } \\
\text { lower pressure }\end{array}$ \\
11 & 1,75 & $-21,86$ & Saturated vapour \\
12 & 1,75 & $-21,86$ &
\end{tabular}

*) Tingkat keadaan berdasar Gambar 1

Laju alir massa refrigeran pada kompresi uap 0,237 kg/s. Kalor yang diserap evaporator besarnya sama dengan total beban pendinginan maksimal yaitu 251922,585 Watt. Kalor yang dikeluarkan oleh kondensor 326560,253 Watt. Kerja kompresor yaitu 74637,668 Watt. Coefficient of Performance (COP) kompresi uap 3,375.

\section{Sistem Refrigerasi Absorpsi}

Tabel 2.

Data Tiap Keadaan untuk Sistem Refrigerasi Absorpsi

\begin{tabular}{|c|c|c|c|c|}
\hline $\begin{array}{c}\text { State } \\
\text { points* }\end{array}$ & $\begin{array}{l}\text { Tekanan } \\
\text { (bar) }\end{array}$ & $\begin{array}{l}\text { Temperatur } \\
\left({ }^{\circ} \mathrm{C}\right)\end{array}$ & $\begin{array}{c}\% \mathrm{~kg} \\
\mathrm{NH}_{3} / \mathrm{kg} \\
m i x\end{array}$ & Kondisi \\
\hline 1 & 12 & 30,94 & $\begin{array}{c}\text { Pure } \\
\text { ammonia }\end{array}$ & $\begin{array}{c}\text { Saturated } \\
\text { vapour }\end{array}$ \\
\hline 2 & 15 & 38,645 & $\begin{array}{c}\text { Pure } \\
\text { ammonia }\end{array}$ & $\begin{array}{c}\text { Saturated } \\
\text { vapour; } \\
P 2=P 3\end{array}$ \\
\hline 3 & 15 & 38,645 & $\begin{array}{c}\text { Pure } \\
\text { ammonia }\end{array}$ & $\begin{array}{l}\text { Saturated } \\
\text { liquid }\end{array}$ \\
\hline 4 & 12 & 30,94 & $\begin{array}{c}\text { Pure } \\
\text { ammonia }\end{array}$ & $\begin{array}{c}\text { Throttling; } \\
\text { isoenthalpy; } \\
\text { lower pressure }\end{array}$ \\
\hline 5 & 12 & 38,645 & $\begin{array}{l}\text { Weak } \\
\text { solution }\end{array}$ & $\begin{array}{c}\text { Liquid } \\
\text { solution; } \\
P 5=P 4=P 1\end{array}$ \\
\hline 6 & 12 & 30,94 & $\begin{array}{l}\text { Strong } \\
\text { solution }\end{array}$ & $\begin{array}{l}\text { Liquid } \\
\text { solution; } \\
P 6=P 1\end{array}$ \\
\hline 7 & 15 & 30,94 & $\begin{array}{l}\text { Strong } \\
\text { solution }\end{array}$ & $\begin{array}{c}\text { Liquid } \\
\text { solution; } \\
P 7=P 8=P 2\end{array}$ \\
\hline 8 & 15 & 38,645 & $\begin{array}{c}\text { Weak } \\
\text { solution }\end{array}$ & $\begin{array}{c}\text { Liquid } \\
\text { solution } \\
\end{array}$ \\
\hline
\end{tabular}

*) Tingkat keadaan berdasar Gambar 1

Kalor yang diserap oleh evaporator sistem absorpsi besarnya sama dengan kalor kondensor sistem kompresi uap yaitu 326560,253 Watt. Laju alir massa refrigerant murni 0,229 kg/s. Kalor kondensor absorpsi 327242,768 Watt. Variasi dilakukan untuk konsentrasi larutan lemah aquos-ammonia 10\%, 20\%, $30 \%$, dan $40 \%$. Variasi yang dilakukan memberikan nilai yang bervariasi pula untuk laju alir massa tingkat keadaan 5, 6, 7, dan 8 serta Q absorber dan Qgenerator.

Tabel 3.

Hasil Perhitungan Variasi Persentase Ammonia pada Absorber

\begin{tabular}{ccccc}
\hline \hline No & $\begin{array}{c}\text { Variasi } \\
\text { Konsentrasi State } \\
\text { Point } 5, c_{5}\end{array}$ & $\dot{m}_{5}(\mathrm{~kg} / \mathrm{s})$ & $\dot{m}_{6}(\mathrm{~kg} / \mathrm{s})$ & $\begin{array}{c}\text { Q absorber } \\
\text { (Watt) }\end{array}$ \\
\hline 1 & 0,10 & 0,286 & 0,515 & 469810,872 \\
2 & 0,20 & 0,381 & 0,610 & 455600,219 \\
3 & 0,30 & 0,572 & 0,801 & 438987,787 \\
4 & 0,40 & 1,145 & 1,374 & 419307,094 \\
\hline \hline
\end{tabular}

Analisis pada generator juga dilakukan dengan memvariasikan persentase ammonia untuk weak solution seperti pada absorber, yaitu $10 \%, 20 \%, 30 \%$, dan $40 \%$, sedangkan untuk strong solution, persentase ammonia tetap yaitu $50 \%$. Weak solution melintasi state point 8 , sedangkan strong solution melalui state point 7.

Tabel 4.

Hasil Perhitungan Variasi Persentase Ammonia pada Generator

\begin{tabular}{|c|c|c|c|c|c|}
\hline No & $\begin{array}{c}\text { Variasi } \\
\text { Konsentrasi } \\
\text { Ammonia } \\
\text { pada State } \\
\text { Point } 8, C_{8}\end{array}$ & $\begin{array}{l}\text { Enthalpi } \\
\text { State } \\
\text { Point } 8, \mathrm{~h}_{8} \\
(\mathrm{~J} / \mathrm{kg})\end{array}$ & $\begin{array}{c}\dot{m}_{8} \\
(\mathrm{~kg} / \mathrm{s})\end{array}$ & $\begin{array}{c}\dot{m}_{7} \\
(\mathrm{~kg} / \mathrm{s})\end{array}$ & $\begin{array}{l}\text { Q Generator } \\
\text { (Watt) }\end{array}$ \\
\hline 1 & 0,10 & 652360 & 0,286 & 0,515 & 461860,724 \\
\hline 2 & 0,20 & 481880 & 0,381 & 0,610 & 447656,942 \\
\hline 3 & 0,30 & 331760 & 0,572 & 0,801 & 430907,091 \\
\hline 4 & 0,40 & 208190 & 1,145 & 1,374 & 411061,495 \\
\hline
\end{tabular}


coefficient of performance (COP) refrigerasi absorpsi terbaik yaitu 0,794 .

\section{Sistem Solar Collector}

Sistem kolektor surya digunakan untuk memanaskan generator absorpsi. Dengan demikian, berdasarkan analisis keseimbangan energi, Q generator akan sama besarnya dengan Q kolektor surya dan dapat diperoleh luasan flat plate solar collector yang dibutuhkan. Berdasarkan hasil perhitungan, diperoleh luas solar collector $301 \mathrm{~m}^{2}$.

Tabel 5.

Hasil Perhitungan Luas Solar Collector

\begin{tabular}{ccc}
\hline \hline $\begin{array}{c}\text { Variasi Konsentrasi } \\
\text { Ammonia untuk Weak } \\
\text { Solution }\end{array}$ & Q Generator (Watt) & $\begin{array}{c}\text { Luas Solar } \\
\text { Collector }\left(\mathrm{m}^{2}\right)\end{array}$ \\
\hline 0,10 & 461860,724 & 337,864 \\
0,20 & 447656,942 & 327,473 \\
0,30 & 430907,091 & 315,220 \\
0,40 & 411061,495 & 300,703 \\
\hline \hline
\end{tabular}

\section{KESIMPULAN/RINGKASAN}

Beban pendinginan tertinggi yaitu bulan Januari pada 15 jam waktu pendinginan sebesar 859595,541 Btu/hr atau 251,922 KW. Nilai Coefficient of Performance (COP) terbaik untuk sistem absorpsi yaitu pada persentase aquos-ammonia untuk weak solution 0,40 dengan COP 0,794.

Luas Flat Plate Solar Collector terkecil yaitu pada variasi persentasi aquos-ammonia untuk weak solution 0,40 yaitu $300,703 \mathrm{~m}^{2}$. Nilai COP untuk sistem kompresi uap yaitu 3,375 dan lebih kecil daripada sistem pendingin Carnot sistem kompresi uap.

Komponen penyusun sistem pendinginan yang dipilih berdasarkan katalog sebagai berikut: a) Evaporator: Merk: Cabero seri IBHR (5 unit 55KW; stainless steel); b) Kompresor:
Merk: Hasegawa; V-Belt Drive Compressor; two-stage compressor unit model HVU-VZL62AVT; c) Katup ekspansi: Merk: HRP; Series TERE, Alco Code A; d) Kondensor Sistem Absorpsi: Merk: Cabero Compact Line seri W-Shape; e) Komponen Absorpsi: Merk: York; model: YHAU-C-L (Kapasitas: 176-1758 kW); f) Flat Plate Solar Collector: Merk: Sunearth Empire Series model EC/EP40 (Gross Area $=40.81$ ft2; 80 unit); g) Pompa: Merk: Flowsereve; GA series; Double Helical Gear (pressure to 17 bar); h) Energy Storage: Merk: Cristopia; Tipe: Concrete Tank

\section{DAFTAR PUSTAKA}

[1] Asosiasi Obat Hewan Indonesia, Jakarta, 2015.

[2] D. P. K. Pamekasan, Interviewee, Produksi dan Populasi sapi potong di kabupaten Pamekasan. [Interview]. 11 May 2015.

[3] S. James and C.James, Meat Regrigeration, England: Woodhead Publishing Limited,Abington Hall,Abington, 2002.

[4] D. N. Basu and A.Ganguly, Solar thermal-photovoltaic powered potato cold storage-conceptual design and performance analysis, p. 308, 2015.

[5] S. J. Michael and H. N. Shapiro, Fundamental of Engineering Thermodynamics 7th Edition, United States of America: John Wiley \& Sons, Inc, 2011

[6] W. Stoecker and J. Jones, Refrigeration and Air Conditioning, New York: McGraw-Hill, Inc., 1982.

[7] American Society of Heating, Refrigerating and Air Conditioning Engineer (ASHRAE), Inc., Cooling and Heating Load Calculation Manual, U.S: U.S Department of Housing and Urban Development, 19761977.

[8] F. P. Incropera and D. P. Dewitt, Fundamentals of Heat and Mass Transfer 6th Edition, United States of America: JOHN WILEY \& SONS, 2007.

[9] Dinas Peternakan Jawa Timur, "Dinas Peternakan Provinsi Jawa Timur," 2015. [Online]. Available: www.disnak.jatimprov.go.id. [Accessed 21 September 2016].

[10] D. N. Basu and A. Ganguly, Solar thermal-photovoltaic powered potato cold storage - Conceptual, p. 311, 2015.

[11] S. Kakac and H. Liu, Heat Exchanger; Selecting, Rating, and Thermal Design 3rd Edition, U.S: Taylor \& Francis Group, LLC, 2012. 